\title{
ON THE EFFECT OF THE MERIDIONAL CONTOUR SHAPE ONTHE POWER CHARACTERISTICS OF A CENTRIFUGAL COMPRESSOR WHEEL
}

\author{
Institute of Technical Mechanics \\ of the National Academy of Sciences of U kraine and the State Space Agency of U kraine \\ 15 Leshko-Popel St., Dnipro 49005, Ukraine; e-mail: yukv@i.ua; zinevich7385@ gmail.com
}

\begin{abstract}
This work is concerned with the development of approaches to the optimal aerodynamic design of centrifugal compressor wheels, which is due to the use of centrifugal stages in compressors of modern aircraft gas turbine engines and power plants. The aim of this work is a computational study of the effect of the meridional contour shape of a centrifugal compressor wheel on its power characteristics. The basic method is a numerical simulation of 3D turbulent gas flows in centrifugal wheels on the basis of the complete averaged Navier-Stokes equations and a two-parameter turbulence model. The computational study features: varying the shape of the hub and tip part of the meridional contour over a wide range, formulating quality criteria as the mean integral values of the wheel power characteristics over the operating range of the air flow rate through the wheel, and a systematic scan of the independent variable range at points that form a uniformly distributed sequence. As a result of multiparameter calculations, it was shown that in the case of a flow without separation in the blade channels of a wheel with a given starting shape of the meridional contour, varying that shape has an insignificant effect on the wheel power characteristics. It is pointed out that in similar cases it seems to be advisable to aerodynamically improve centrifugal wheels by varying the shape of their blades in the circumferential direction rather than in the meridional plane. This conclusion was made using rather a "coarse" computational grid, which, however, retains the sensitivity of the computed results to a variation in the centrifugal wheel geometry. On the whole, this work clarifies ways of further aerodynamic improvement of centrifugal compressor impellers in cases where the starting centrifugal wheel is a well-designed wheel with a flow without separation in the blade channels. The results obtained may be used in the aerodynamic optimization of centrifugal stages of aircraft gas turbine engines.
\end{abstract}

Keywords centrifugal compressor wheel, meridional contour, Bezier curve, numerical simulation, power characteristics.

1. Benini E., Giacometti S. Design, manufacturing and operation of a small turbojet-engine for research purposes. Applied Energy. 2007. V. 84. Pp. 1102-1116. https://doi.org/10.1016/j.apenergy.2007.05.006

2. Schiffmann J., Favrat D. Design, experimental investigation and multiobjective optimization of a small-scale radial compressor for heat pump applications. Energy. 2010. V. 35. Pp. 436-450. https://doi.org/10.1016/j.energy.2009.10.010

3. Rekstin A. F., Galerkin Yu. B. Features of the primary design of low-flow centrifugal compressor stages Vestnik Permskogo Natsionalnogo Issledovatelskogo Universiteta. Mashinostroyeniye, Materialovedeniye. 2018. V. 20. No. 2. Pp. 43-54. (in Russian). https://doi.org/10.15593/2224-9877/2018.2.06

4. Poursadegh F., Hajilouy A., Nili M. A novel quasi-3d design method for centrifugal compressor impeller on the blade-to-blade plane. Proc. of ASME TURBO EXPO 2011. (Vancouver, June 6-10, 2011). Vancouver, British Columbia (Canada), 2011. 8 pp. https://doi.org/10.1115/GT2011-45451

5. Verstraete T., Alsalihi Z., Van den Braembussche R. A. Multidisciplinary optimization of a radial compressor for microgas turbine applications. Journal of Turbomachinery. 2010. V. 132. Pp. 34-41. https://doi.org/10.1115/1.3144162

6. Xiaomin Liu, Wenbin Zhang. Two schemes of multi-objective aerodynamic optimization for centrifugal impeller using response surface model and genetic algorithm. Proc. of ASME TURBO EXPO 2010. (Glasgow, June 14-18, 2010). Glasgow (UK), 2010. 13 pp.

7. Jin-Hyuk Kim, Jae-Ho Choi, Kwang-Yong Kim. Design optimization of a centrifugal compressor impeller using radial basis neural network method. Proc. of ASME TURBO EXPO 2009. (June 8-12, 2009). Orlando, Florida (USA), 2009. 9 pp.

8. Vasil'ev Yu. S., Galerkin Yu. B., Soldatova K. V. Turbomachine flow passage optimization (by the example of centrifugal compressors) (in Russian). Problemy Energetiki. 2011. No. 9-10. Pp. 105-117. 
9. Kvasha Yu. A., Zinevych N. A. Aerodynamic improvement of centrifugal compressor stage impellers Teh. Meh. 2019. No. 1. Pp. 57-67. (in Russian).

https://doi.org/10.15407/itm2019.01.053

10. Sobol' I. M., Statnikov R. B. Choice of Optimum Parameters in Multicriteria Problems Moscow: Nauka, 1981. 110 pp. (in Russian).

11. Pis'menny V. I., Kvasha Yu. A. Calculation of a 3D turbulent air flow in a centrifugal compressor stage Teh. Meh. 2004. No. 2. Pp. 94-99. (in Russian).

Received on September 8, 20202, in final form on September 22, 2020 